\title{
Kerja Sama Antar Umat Beragama: Pilihan Masyarakat Majemuk
}

\author{
Machasin
}

\begin{abstract}
Religion is a way of life by which God give to the mankind in order to make them aware their humanity and their duty to worship God. But we are facing the condition in which in the name of God and religion, people kill each other due to their pity and narrow mind in understanding their religion. Religion decreasing in its meaning to merely a tradition of the religion and few religious leaders take benefit from this situation to maintain his domination in society. Religious followers shouldn't have perception that people from different religions are their enemy as long as they do not make any hurts towards their belief and activities, and again, people should not force their belief to people of different religions. Interfaith relation should be based on the duty that people must respect each other and working together in the field of human relation very homogen society without loosing their belief, as the meaning of religion is to bring people to humanity and peace.
\end{abstract}

$\mathrm{K}$ onflik-konflik berdarah yang terjadi hampir dalam seluruh rentangan sejarah agama-agama di dunia dan sangat banyak terjadi akhir-akhir ini di tanah air menimbulkan pertanyaan mengenai kemampuan umat beragama untuk membangun suatu peradaban yang kuat lagi santun bagi suatu masyarakat majemuk seperti Indonesia. Pesimisme didasarkan pada gejala-gejala menguatnya pandangan sempit pada banyak kelompok agama yang menganggap bahwa agamanyalah satusatunya agama yang benar dan karenanya orang lain harus mengakui kebenarannya dan boleh dijadikan obyek dakwah. Kalau tidak mau menyambut positif dakwah itu, orang-orang seperti itu seharusnya tidak diberi hak yang sama dengan hak-hak orang-orang dari kelompok itu. Orang-orang yang berpendapat seperti ini merasa cukup mampu bekerja dan hidup dengan kelompoknya sendiri, tanpa harus bekerja sama dan berbagi dengan orang-orang lain di luarnya.

Demikian pula gejala menguatnya emosi "keagamaan" yang tak terkendali dan mudah dibakar dengan isu-isu yang menggambarkan kejahatan umat lain atas umat sendiri, sehingga memicu tindakantindakan destruktif. Pesan kearifan agama dan anjuran para penganjur agama untuk mengendalikan nafsu tidak berdaya menghadapi kobaran emosi yang disemangati oleh tindakan membela nama Tuhan. Tidak jarang bahkan agama menjadi semacam pengobar nafsu merusak yang sangat sulit dikendalikan, karena orang menganggapnya sebagai sesuatu yang terpuji. Membela agama, walaupun dilakukan dengan penuh nafsu dan merugikan orang lain, sering kali menjadi dalih yang membenarkan pelampiasan kejengkelan, ketidaksukaan, keirian dan hal-hal serupa. 
Akan tetapi, di samping itu ada juga terdengar hal-hal yang dapat memberikan optimisme. Umat beragama mempunyai tradisi yang sangat panjang dan di dalamnya terdapat ajaran-ajaran yang dapat dikembangkan menjadi suatu landasan kebersamaan hidup untuk mencapai kemuliaan martabat umat manusia. Toleransi dan ajaran kasih terhadap sesama ada pada setiap agama yang berkembang di bumi ini. Demikian pula ajaran tentang sikap rendah diri yang dapat dikembangkan menjadi kesediaan untuk menghormati orang lain. Penundaan penilaian atas kebenaran kepercayaan orang lain sampai saat semua menghadap Tuhan Yang Maha Esa dan Maha Bijaksana terdapat pula dalam ajaran agama. Walaupun ada banyak orang yang akan tidak setuju dengan ini, pertimbangan akal sehat dapat menerimanya. Jika masing-masing pengikut agama merasa bahwa agamanyalah yang benar, sementara pembuktian empiris tidak dapat ditemukan dan pembuktian rasional tidak memuaskan semua pihak, maka sikap yang terbaik adalah menunda penilaian sampai ada hakim adil yang keputusannya akan diterima semua pihak. Hakim itu tidak lain adalah Tuhan yang diakui keberadaanNya oleh semua pihak yang bertikai.

Sementara itu, kehidupan nyata di dunia mengharuskan orang untuk bertemu, berkomunikasi dan bekerja samawalaupun mungkin tanpa harus secara sadar bersepakat-dengan orang-orang lain. Untuk semua jenis relasi seperti ini sudah barang tentu diperlukan aturan bersama yang idealnya dibuat oleh pihak-pihak yang dianggap mewakili kepentingan bersama.

\section{Kelahiran dan Misi Agama}

Agama-agama lahir sebagai respon terhadap kehidupan manusia yang menyimpang dari hakikat kemanusiaan. Dalam al-Qur'an terdapat berbagai sebutan untuk penyimpangan ini, seperti: kesesatan, jalan bumi, jalan dunia dan jalan syetan. Agama, yang juga ditandai dengan penyebutan perhatian kepada ayat-ayat Allah, dimaksudkan untuk mengangkat manusia dari kehidupan buminya, menuju kehidupan rohaniah yang jauh lebih mulia, sesuai dengan hakekat keberadaannya sebagai pemegang amanah Allah. Misalnya, dinyatakan:

Dan bacakanlah kepada mereka (wahai Muhammad), berita seseorang yang Kami berikan kepadanya ayat-ayat Kami, kemudian ia menarik dirinya dari ayat-ayat itu lalu ia diikutioleh syetan, maka ia termasuk orang-orang yang sesat. Jika Kami kehendaki niscaya Kami angkat ia dengan ayat-ayat itu, tetapi ia lekat kepada bumi dan menurutkan hawa nafsunya; maka perumpamaannya seperti anjing: jika engkau menghalaunya, ia menjulurkan lidahnya, dan jika engkau membiarkannya, ia juga menjulurkan lidahnya. Demikianlah perumpamaan orang-orang yang mendustakan ayat-ayat Kami. Maka ceritakanlah kisah-kisah itu supaya mereka berfikir. (Surat 7/alA'râf: 175-6)

Penyimpangan terjadi karena manusia menuruti ajakan nafsu atau jalan bumi, yakni mengikuti dorongan-dorongan biologis dengan keinginan-keinginan badaniah, dan melupakan hal-hal yang berisifat ruhaniah. Dakwah agama mengajak manusia untuk mengikuti jalan Tuhan, jalan yang membuat manusia bermartabat sebagai manusia.

Dalam perkembangannya, agama terlibat dengan tuntutan-tuntutan dan persoalan-persoalan kehidupan manusia. Penghayatan agama berinteraksi dengan 
hubungan antar manusia, keperluan ekonomi, kebutuhan akan keadilan dan sebagainya. Muncul kemudian tindakantindakan destruktif dan tidak manusiawi dengan label kesucian agama. Mengapa ini terjadi? Karena manusia mempunyai pembawaan hewaniah dan nafsu-nafsu badaniah, di samping nalar dan nurani yang sebenarnya-kalau dipergunakan dengan sebaik-baiknya-dapat membuat keseimbangan dalam kehidupannya.

Agama apa pun selalu terbentuk dalam kompleksitas budaya. Walaupun ada halhal yang diyakini berasal dari Allah dan karenanya dianggap bersifat ilahiah, agama dalam bentuknya yang dihayati dan diamalkan oleh penganutnya adalah sebuah produk budaya. ${ }^{1}$ Artinya, agama terbentuk dalam interaksi manusia dengan sesamanya dan dengan lingkungannya. Berbeda dengan hewan yang mengikuti undang-undang alam, manusia membentuk sendiri sebagian besar dari undang-undang kehidupannya yang terwujud dalam filosofi, tradisi, nilai-nilai, hukum dan aturan yang merupakan unsurunsur kebudayaan dalam interaksi itu. Pembentukan itu, selain menggunakan pertimbangan-pertimbangan kesadaran, juga melibatkan ketidaksadarannya. Tradisi keagamaan pun mengandung hal-hal yang tidak semuanya disadari dan sampai batas tertentu tidak dapat dikuasai manusia sendiri, seperti bencana alam, kesalahan kalkulasi, spontanitas dan keterlanjuran. ${ }^{2}$ Karena itu, di samping peyebab lain, seperti perubahan keadaan yang membuat tradisi tidak lagi sesuai dengan tuntutan kehidupan, dalam perjalanan sejarah umat manusia selalu ditemukan peninjauan kembali terhadap tradisi-tradisi yang ada. Termasuk di antara yang ditinjau kembali itu, semestinya, adalah teologi atau rumusan ajaran agama yang mendukung sikap eksklusif, menolak keberadaan orang lain.
Sayangnya, ada kecenderungan dalam diri pemeluk agama untuk menganggap suci tradisi keagamaan seperti itu. Ini bisa jadi disebabkan oleh kekerdilan jiwa generasi baru dalam hubungannya dengan capaiancapaian besar generasi sebelumnya. Di hadapan karya al-Ghazali, Ihyâ' 'Uluam al-Dîn, misalnya, banyak orang yang tidak berani menggunakan daya kritisnya, karena karya itu begitu besar dan mengagumkan. Orang lalu hanya menerimanya sebagai suatu ajaran suci yang bernilai ilahiah, dengan tugas seorang muslim sekarang hanyalah mempelajari dan mengamalkannya. Sebab lain yang perlu disebut di sini adalah kepentingan. Tradisi agama dapat memberikan kedudukan tertentu dan kekuatan tertentu dalam kehidupan. ${ }^{3}$ Dengan demikian, jika tradisi ini dapat menjamin keadaan yang menguntungkan bagi elite keagamaan, sangat besar kemungkinan mereka untuk menjaganya agar terus berlangsung. Salah satu cara menjaga kelangsungan ini adalah memberikan cap sakral kepadanya, karena

1 Budaya pada intinya adalah hasil pengolahan manusia atas dirinya sendiri dan lingkungannya, walaupun secara keseluruhan terikut juga di dalamnya hal-hal yang luput dari perhitungannya dan tidak direncanakannya.

2 Ingat peristiwa pemilihan Abu Bakr sebagai pengganti Nabi Muhammad saw. dalam memimpin masyarakat Islam generasi pertama. Peristiwa ini oleh 'Umar bin alKhattab disebut faltah yang kaum Muslimin dihindarkan oleh Allah dari akibat negatif yang sangat muncul daripadanya. Faltah dapat diartikan dengan kejadian yang terjadi dengan tiba-tiba, tanpa perencanaan.

${ }^{3}$ Sebagai gambaran, dapat dibaca tulisan Taufik Abdullah, "Agama sebagai Kekuatan Sosial", dalam Taufik Abdullah dan M. Rusii Karim, Metodolgi Penelitian Agama; Sebuah Pengantar (Yogyakarta: Tiara Wacana, 1989), 29-39. 
sesuatu yang sakral mesti dipertahankan dan tidak boleh dikutak katik.

\section{Individu dan Kelompok Lepas}

Walaupun agama, karena sifat hubungannya dengan yang gaib, selalu mewujud dalam hubungan pengelompokkan berjenjang dan di dalamnya ada kecenderungan kuat untuk membangun hierarki imam-pengikut, selalu saja ada ruang untuk ekspresi individual yang berbeda dengan ekspresi "resmi". Lebih dari itu, bisa jadi sebagai pengembangan dari ungkapan individual ini atau karena sebab lain, banyak sekali muncul ungkapan-ungkapan kelompok yang berdiri sendiri, bebas dari jama'ah "resmi" yang dianggap (atau menyatakan diri?) representatif dari pengikut agama tertentu. "Lâ ikrâh fi al-dîn", tidak ada paksaan dalam agama, demikian kata alQur'ân. ${ }^{4}$ Walaupun sebenarnya berbicara mengenai kebebasan manusia untuk beriman atau tidak beriman kepada apa yang dibawa al-Qur'an, ayat ini memberikan pesan juga bahwa perwujudan keimanan dalam kenyataan kehidupan pun tidak dapat dipaksa. Memang ada kecenderungan untuk memformalkan ekspresi keimanan, namun orang tetap mempunyai kebebasan asasi untuk menentukan sendiri ekspresi keimanannya. Apakah sesuatu yang diyakini seorang pemeluk agama sebagai ekspresi keimanan kemudian akan diterima oleh orang-orang seagama sebagai sebuah ekspresi keimanan atau tidak, itu persoalan lain. ${ }^{5}$

Karena itu, wajarlah munculnya kelompok-kelompok dalam setiap agama. Sebenarnya ada dua hal yang bertentangan dalam kecenderungan beragama: Di satu pihak, orang bebas untuk mengambil bentuk ekspresi keimanannya, namun di pihak lain, orang juga berkecenderungan untuk bergabung dengan orang-orang lain dalam mewujudkan keberagamaannya. Seorang tokoh ilmu agama, Joachim Wach, mengatakan sehubungan dengan ini bahwa pengalaman keagamaan dapat diungkapkan dalam bentuk fellowship, yakni pengelompokan diri dalam jama'ah, di samping pengungkapan dalam action, atau tindakan seperti pemberontakan dan sweeping tempat-tempat maksiat, dan dalam thought, yakni pemikiran mengenai berbagai hal dalam kehidupan. ${ }^{6}$

Dasar agama yang paling penting adalah keyakinan yang tidak selalu dilanjutkan dengan penalaran. Penalaran dalam agama sering kali hanya dilakukan oleh sedikit tokoh pemikir. Di atas keyakinan ini dibangun ajaran oleh tokoh-tokoh yang kemunculannya tidak direncanakan oleh umat manusia dan tidak jarang terjadi perbedaan-perbedaan di antara mereka. Dengan demikian, terdapat banyak variasi dalam beragama. Ketika kemudian muncul kekuasaan yang mendukung satu pemikiran atau rumusan ajaran, muncullah ortodoksi, kelompok pemegang ajaran yang "dianggap" asli dan benar.

Selain itu, orang juga berkelompok atau memisahkan diri dari kelompok karena persoalan-persoalan yang berbeda-beda. Pada mulanya bisa jadi orang-orang yang memisahkan diri dari kelompok, lalu membuat kelompok lain, masih menganut tradisi dan ajaran keagamaan yang sama

${ }^{4}$ Lihat surat 2/al-Baqarah: 256.

5 Lihat presentasi penulis, "Faith and Identity", dalam acara "The Christian-Muslim Dialogue Consultation" yang diadakan oleh Lutheran World Federation (LWF Geneva) di UKDW Yogyakarta, 4-6 April 2002.

' Lihat bukunya, The Comparative Study of Religion, ed. Joseph M. Kitagawa (New York: Columbia University Press, 1958). 
rdenganl iyang-rdianutskelompokizyang ditinggalkannyarAkan tetapirketika zaman , berganti dan anggota kelompok bertambah - terutama :ketikarkomunikasi 'dengan kelompok: pertama tidak lagi terjalin - perbedaan=perbedaan lalu muncul: $\quad \cdots$ -

$\therefore$ 'Prinsip-prinśip keimanan dari kelòmpok-kelomipok' sejperti ini bîsa' jadi tidak sberbeda déñgañ kelömpok "résmi", namun

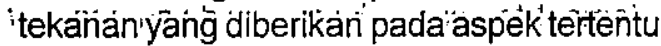
'dari ajaran' séring kali sangat 'kuat 'dan berbeda dengan tekanàn yang diberikan oleh yang tersebut terakhir. Misalnya, pada bentuk peribadatan formal, pada kekerasan tindakan atas penyimpangan moral, pada kegiatan politik dan pada perekrutan anggota. Tekanan-tekanan ini menjadi ciri khas dari masing-masing kelompok dan pada gilirannya tidak.jarang'menimbulkan konflik-konflik..Sifat kebebasannya, tidak jarang juga menyebabkan kesulitan dialog dan pembinaan kerukunan di -antara kelompok-kelompok umat seagama. Konflik dan permusuhan sering kali lebih keras terjadi antara kelompok-kelompok umat seagama dari pada antara umat satu agama dan umat agama lain.

$\therefore$ Sebenarnyakalau perbedaan ini dapat - digarap dengan baik; ada banyak hal positif yang dapat dikembangkan. Misalnya, bahwa dengan banyaknya ekspresi=ekspresi i itu i pilihan praktek keagamaan menjadi lebih : banyak:Inimemberikan'peluang yang lebih -besar: bagi : perencanaan-masa depan, daripada kalau pilihannya sedikit. Syaratnya adalah bahwa perbedaan=perbedaan-itu yang kebanyakan:bukan pada pokok ajaran - didialogkan dengan cara:yang jauh dari ménghakimiđdan memäksakan pénemuan

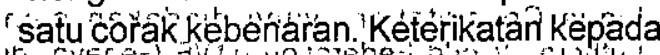

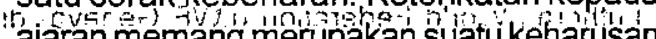
ajaran memang merupakan suatu keharusan bagi setiap pemeluk agama namun nurani yang sdidasari keimanan mempunyai

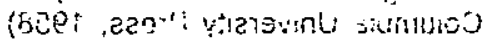

- tanggung:jäwab:pula untuk mempertanyakan kebenaran tindakan dan pilihan-pilihan sikap, dengan pertimbangan nalar. Tanpa itu, lalu manusiątidak dapatmerasakan.kéhàdiran agama sebagai suatu bentuk kasih sayang Tuhan kẻpada kèseluruhan ưmat manusia.

\section{Kläim Kếbenaran}

'r.... "5: 1,Terdapat kekacauan: dalam:melihat ' hakikatsagama; antara; (1);yang ‘ bersifat i keyakinan personal, (2) yang bersifat umum rdalam aliran-aliran yang berbeda dari agama yang sama, dan (3) yang sebenarnya bersifat universal dalam_setiap, agama. Apa.yang -dianggap-benar dalam tataran pribadi, walaupun tidak jarang dipakai untuk mengukurskebenaran umum, sebenarnya belum tentu benar, karena kelemahan yang -melekat pada individu, seperti pandangan yang hanya terbatas pada satu dua aspek saja dari: kenyataan, 'tidak' konprehensif. Untuk mencapai pandangan komprehensif, perlu pandangan orang lain dari aspek yang - lain=lagi. "Sebaliknya, ..ada; hal-hal yang sebenarnya:sama-sama dimiliki oleh șetiap agama $_{, \text {, namun }}$ dianggap -oleh pemeluk agama tertentu hanya ada pada agamanya. Misalnya; :ajaran tentang!.penghargaan . kepada:smartabat 'manusiarkejujuran, keadilan dan,pengendalian:diri.;Anggapan isepertisinistimbulsantara lain ikarena fanatisme-buta:kepada; ajaran-atau,tradisi - agamarsendirirdan ketidaktahuan -akan tradisi agama:lain. Demikian pula mengenai rhal-hal yang,khas, dalam satu=agama:dan dipegangi oleh setiap aliran yang ada di - dalamnya, pengikut suatu aliran tidak jarang menganggap bahwa halitu hanya ada dalam

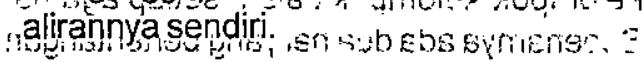
$u^{*} s$ - Kekacauan dalammelihat ketiga ranah :ikebenaran ini dapat menyebabkan pemeluk agamacenderung untuk mengánggap benar :pemahamanudan penghayatan agama 
sendiri dan menganggap salah pemahaman dan penghayatan yang berbeda dengan itu.

Untuk dapat menimbang hal ini dengan lebih baik perlu diingat beberapa hal. Pertama, orang dapat melihat dengan mudah bahwa agama menuntut komitmen mutlak dari para pemeluknya terhadap ajaranajarannya dan karenanya timbul pemutlakan kebenaran agama. Akan tetapi, kita juga tahu, tidak ada jaminan bahwa ajaran suatu agama meru-pakan satu-satunya yang benar. Benarkah Tuhan yang disembah oleh para pemeluk suatu agama merupakan sebenar-benarnya Tuhan? Jawabannya dapat ya, dapat juga tidak, karena Tuhan di situ merupakan hasil konsepsi manusia. Kalau demikian keadaannya, mengapa kepercayaan seperti itu mesti dimutlakkan kebenarannya? Ada kemungkinan salah pada setiap konsepsi, dan karenanya sikap yang paling wajar adalah menghargai konsepsi-konsepsi yang telah dihasilkan oleh setiap orang. Mungkin dapat diadakan dialog di sini, namun dialog bukan untuk menemukan mana yang paling sesuai dengan akal atau yang paling kuat argumennya, melainkan untuk saling menimba pengalaman dan memperkaya pemahaman. Bagaimana pun konsepsi itu dimaksudkan untuk menangkap Yang Kudus, Yang Transendental sekaligus Yang Gaib. Ketika disebut dengan penyebutan ini, kiranya tidak dapat disangkal bahwa semua agama mempunyai sakralitas yang satu, namun konsepsi mengenainya berbeda-beda.

Kedua, kebanyakan orang tidak melakukan pemilihan dan penyelidikan dengan seksama terhadap ajaran agama tertentu sebelum menjadi pengikutnya. Agama biasanya diterima begitu saja dari orang tua atau lingkungan. Memang ada orang-orang yang melakukan pemilihan, perbandingan dan seleksi yang ketat, namun jumlah mereka sangat kecil dibandingkan dengan yang menerima agama secara tidak sadar. Baru setelah orang masuk dalam suatu agama, timbul usaha untuk lebih memahami agamanya dan "mungkin" (dalam kasus yang juga sangat jarang) mengenal serba sedikit ajaran agama lain. Biasanya pengetahuan mengenai agama lain ini pun berasal dari orang seagama yang dalam banyak hal terpengaruh oleh warisan sejarah pertikaian antar pemeluk agama yang berbeda. Akibatnya agama lain itu dianggap sebagai musuh dan setiap musuh hampir selalu digambarkan secara negatif. ${ }^{7}$

Artinya, pengakuan bahwa agama sendiri merupakan satu-satunya agama yang benar, sementara agama lain pasti salah, sering kali tidak didukung bukti yang kuat dan sikap yang jujur dan netral. Keputusan sepihak lebih menentukan dalam hal ini dan ikatan emosional merupakan penguatnya kalau bukan dasarnya yang paling bawah. Padahal, kalau dipikir-pikir dengan seksama dan jujur semua agama mengakui akan adanya yang kudus, sementara yang kudus ini tidak dapat ditangkap dan digambarkan dengan jelas. Ibaratnya seperti orang buta yang menangkap sebagian dari tubuh gajah dan berusaha menggambarkan keseluruhannya. Masing-masing agama mengembangkan konsepsi tentang Tuhan sesuai dengan penangkapannya. Memang orang dapat mengatakan bahwa konsepsi itu didasarkan atas "Firman Tuhan" sendiri, namun harus diingat bahwa setiap "Firman Tuhan" itu tertuang dalam bahasa tertentu. Bahasa tertentu itu mempunyai aturan-aturan dan

${ }^{7}$ Lihat misalnya Karel A. Steenbrink, "Images of Islam in Dutch Society", makalah sumbangan untuk Konferensi Hubungan Islam-Kristen, Jakarta 7-9 Agustus 1997. 
kebiasaan-kebiasaan yang sesuai dengan pandangan para pemakainya tentang kenyataan. Misalnya, bahwa Tuhan dalam al-Qur'an tergambarkan sebagai sosok berpribadi dengan sifat-sifat "kemanusiaan" (seperti "duduk di atas tahta, maha pengasih, maha penyayang dan maha pembalas dendam"). Ini "terpaksa" terjadi karena bangsa Arab pada waktu al-Qur'an turun memandang kenyataan dari pandangan konkret saja. Penggambaran Tuhan yang abstrak akan sangat sulit dipahami dan menjadi tidak mungkin diungkapkan dengan bahasa yang tersedia.

Dengan demikian, seharusnyalah orang menghilangkan penggambaran pengikut agama lain sebagai musuh ini untuk dapat hidup dalam kemajemukan secara harmonis. Ini memang tidak mu-dah. Pengakuan yang jujur akan kemungkinan "kesalahan" (di samping kebenaran yang biasanya diklaim adanya pada diri sendiri) dalam konsepsi sendiri dan kemungkinan "kebenaran" pada orang lain, sudah barang tentu juga diperlukan. Setidak-tidaknya, dengan rendah hati perlu diakui bahwa tidak ada bukti rasional dan obyektif mengenai kebenaran hanya satu agama. Di lain pihak, perlu diingat juga bahwa dalam setiap tradisi atau ajaran agama bisa saja ditemukan halhal yang tidak masuk akal, namun itu tidak berarti bahwa keseluruhan ajaran agama yang mengandung hal seperti itu lalu salah secara keseluruhan. Sebagai sebuah sistem, agama mempunyai kemampuan besar untuk merevisi rumusan-rumusan ajaran dan konsep-konsepnya terus menerus.

\section{Pilihan-pilihan dalam Agama}

Dalam menjalankan agama seseorang tidak hanya berhadapan dengan Tuhan yang terwakili atau terwujud dalam kitab suci, melainkan juga setumpuk tradisi keagamaan. Baik di dalam teks-teks suci maupun tradisi keagamaan terkandung banyak sekali pilihan dari yang lunak nan lembut sampai yang keras nan kasar. Pribadi yang beriman, ketika berhadapan dengan masalah-masalah kehidupan mesti menentukan pilihan kontekstual dengan penuntun iman dan takwa, terhadap kemungkinan-kemungkinan sikap yang ditawarkan oleh tradisi agamanya. Totalitas kepribadiannya, termasuk kecerdasan pikirnya, temperamennya, kepentingannya dan harga dirinya ikut serta dalam menentukan pilihan itu.

Ketika orang melakukan pemilihan, alat terpenting yang dipakainya adalah nalar yang mampu memilah mana nyata dan yang angan-angan, mana yang baik dan mana yang buruk. Memang orang dapat mengatakan bahwa nalar manusia mengandung kelemahan, namun ini tidak berarti bahwa nalar mesti ditinggalkan, terutama ketika berhadapan dengan teks suci. Harus diakui bahwa nalar individual mengandung kemungkinan salah yang sangat besar, walaupun latihan-latihan dan pendidikan yang baik akan dapat menguranginya. Oleh karena itu, diperlukan perujukan kepada hal-hal di luar nalar individual untuk mengurangi kesalahannya. Di antaranya adalah nalar-nalar orang lain yang mungkin melihat masalah dari sudut pandang lain. Konsep ljmak yang disebut sebagai salah satu sumber hukum Islam, semestinya tidak dipergunakan hanya dalam Fiqih, melainkan juga dalam bidangbidang lain yang memerlukan penalaran manusia.

Di dalam Al Qur'an terdapat beberapa ayat yang mengisyaratkan bahwa pluralitas merupakan sesuatu yang alamiah. Allah tidak menghendaki manusia untuk menjadi satu umat saja. 
Kalau Allah menghendaki, niscaya Dia menjadikan kalian satu umat saja, tetapi Allah menyesatkan siapa yang dikehendaki-Nya dan memberi petunjuk kepada siapa yang dikehendaki-Nya. Sesungguhnya kamu akan ditanya tentang apa yang telah kamu kerjakan. (Surat 16lalNahl:93).

Kalau Allah menghendaki,niscaya Dia menjadikan kalian satu umat saja, tetapi memasukkan dalam rahmat-Nya siapa pun yang dkehendaki-Nya, sedangkan orang-orang yang zalim tidak mempunyai pelindung maupun penolong. (Surat 42/al-Syûrâ:8).

Juga dinyatakan bahwa masing-masing kelompok manusia mempunyai jalan hidup yang memang cocok untuk mereka. Perbedaan itu memang merupakan sesuatu yang alami dan karenanya yang penting adalah bagaimana masing-masing kelompok dapat berbuat untuk kebaikan umat manusia.

Kami telah menurunkan kapadamu Alquran dengan kebenaran, membenarkan kitab-kitab yang sebelumnya, dan sebagaibatu ujian terhadap kitabkitab itu. Karena itu, putuskanlah perkara mereka menurut apa yang Allah turunkan dan janganlah kamu mengikuti hawa nafsu mereka dengan meninggalkan kebenaran yang telah datang kepadamu. Untuk tiap-tiap umat di antara kamu, Kami berikan aturan dan jalan yang terang. Sekiranya Allah menghendaki, niscaya kamu dijadikan-Nya satu umat saja, tetapi Allah hendak menguji kamu terhadap pemberian-Nya kepadamu, maka berlomba-lombalah berbuat kebajikan. Hanya kepada Allah-lah kembali kamu semuanya, lalu diberitahukanNya kepadamu apa yang telah kamu perselisihkan itu. (Surat 5/a/Mâidah:48).

Sebagaimana tersebut dalam ayat ini, perbedaan itu tidak perlu diperdebatkan sekarang, yakni pada saat orang tidak sanggup untuk keluar atau melepaskan diri dari apa yang diyakininya sebagai kebenaran. Allahlah nanti yang akan menentukan mana yang benar. Sikap yang seharusnya diambil sekarang adalah membiarkan masing-masing orang berbuat menurut apa yang diyakininya sebagai benar.

Katakanlah, "Tiap-tiap orang berbuat menurut keadaannya masing-masing." Maka Tuhanmu lebih mengetahui siapa yang lebih benar jalannya. (Surat 17) al-lsrâ':84).

Akan tetapi, perbedaan jalan itu tidak menghalangi orang yang ada dalam kelompok tertentu untuk menyampaikan "kebenaran" kepada orang yang ada dalam kelompok lain. Ini terutama berkenaan dengan hal-hal yang merupakan issu bersama.

Katakanlah, "Hai Ahli Kitab, marilah kita mengambil satu prinsip dasar untuk kita: bahwa kita menyembah selain Allah, tidak mempersekutukan Dia dengan sesuatu pun dan tidak pula sebahagian kita menjadikan sebahagian lain tuhan selain Allah." Jika mereka berpaling, maka katakanlah, "Saksikanlah, bahwa kami adalah orang-orang yang menyerahkan diri kepada Allah." (Surat 3/Âl 'Imrân:64).

Dalam penyampaian "kebenaran" itu tidak boleh ada pemaksaan. Yang boleh dan semestinya dilakukan hanyalah mengingatkan.

...maka berilah peringatan, karena sesungguhnya kamu hanyalah orang yang memberi peringatan. Kamu bukanlah orang yang berkuasa atas 
mereka, tetapi orang yang berpaling dan kafir, maka Allah akan mengazabnya dengan azab yang besar. (Surat 88/al-Gasyiyah).

Setelah peringatan-peringatan disampaikan dan ternyata orang yang diperingatkan itu tidak mau juga "jalan kebenaran", keyakinan dan ritual-ritual menjadi urusan masing-masing.

Katakanlah, "Hai orang-orang kafir, kami tidak menyembah apa yang kalian sembah dan kalian pun tidak menyembah apa yang kami sembah. Aku pun tidak menyembah apa yang kalian sembah dan kalian pun tidak menyembah apa yang aku sembah. Bagimulah agamamu dan bagikulah agamaku. (Surat 109/al-Kâfirûn:6).

Orang dapat saja sangat menginginkan orang lain mengikuti jalan kebenaran, tetapi keputusan untuk ikut atau tidak terserah kepada orang lain itu, bukan orang yang menginginkan. Rasulullah pun tidak; karena di situlah letak ujian atas manusia. Ini dilukiskan dengan sangat indah dalam surat 18/al-Kahf:

Maka barang kali kamu akan membunuh dirimu karena bersedih hati sesudah mereka berpaling, sekiraya mereka tidak percaya kepada cerita Alquran ini? Sesungguhnya Kami telah menjadikan apa yang ada di bumi perhiasan baginya, agar Kamimenguji mereka siapakah di antara mereka yang terbaik perbuatannya.

Kesimpulan yang dapat ditarik dari ayat-ayat yang diktutip di atas adalah bahwa pluralitas merupakan sesuatu yang alami dan tidak harus dihindari. Memang ada tersirat kebenaran tunggal dalam pernyataan-pernyataan itu, tetapi kebenaran tunggal itu tidak mesti mengharuskan manusia untuk memaksakannya atas orang lain yang tidak mau menerimanya.
Kewajiban utnuk menyeru orang kepada jalan terbaik terus saja mesti dijalankan, kecuali pada orang-orang yang sudah tidak dapat "diubah" lagi. Kepada orang-orang seperti ini sikap yang tepat adalah pernyataan perbedaan ("Bagimu agamamu dan bagiku agamaku", "Tiap-tiap orang berbuat menurut keadaannya masingmasing"), dengan tetap tidak meninggalkan pergaulan dan perlombaan untuk berbuat yang terbaik bagi umat manusia.

Di dalam Alquran juga terdapat ayatayat yang menyiratkan atau menyatakan bahwa ajaran agama-agama pada dasarnya berasal dariAllah dan bahwa kaum Muslimin seharusnya tidak membeda-bedakan ajaran para Rasul.

Sesungguhnya Kami telah mengutus rasul pada tiap-tiap umat, untuk menyerukan, "Sembahlah Allah dan jauhilah Taghut. ${ }^{8}$ (Surat 16/an-Nahl:36). (Kata Rasulullah dan kaum mukminin) ... Kami tidak membeda-bedakan seorang pun dari Rasul-Rasul-Nya. (Surat 2/al-Baqarah:285).

Dinyatakan pula bahwa setiap bangsa telah diseru oleh utusan Allah, yang menyeru dengan bahasa yang dimengeri oleh bangsa itu.

Sesungguhnya Kami tidak mengutusmu melainkan sebagai pemberi kabar gembira dan pemberiperingatan. Pada setiap bangsa, pastilah pernah ada pemberi peringatan. (Surat 35/ Fâtlir:24).

Kami tidak mengutus seorang rasul pun melainkan dengan bahasa kaumnya. (Surat 14/lbrâhîm:4).

8 Yakni syetan atau apa saja yang disembah selain Allah. (Surat 16/an-Nahl:36). 
Juga bahwa pada tempat-tempat ibadah, dari agama-agama yang berbedabeda, banyak disebut nama Allah.

Seandainya Allah tiada menolak keganasan sebahagian manusia dengan sebahagian yang lain, tentulah telah dirobohkan biara-biara Nasrani, gereja-gereja, rumah-rumah ibadah orang Yahudi dan masjid-masjid, yang di dalamnya banyak disebut nama Allah. (Surat 22/al-Haij:40).

Kami tidak mengutus seorang rasul pun melainkan dengan bahasa kaumnya supaya ia dapat memberikan penjelasan kepada mereka. (Surat 14) Ibrâhîm:4).

Akan tetapi, tidak dapat diingkari pula adanya ayat-ayat yang bersikap bermusuhan. Misalnya, ayat yang menyatakan bahwa orang Yahudi dan Nasrani tak akan puas sebelum Nabi Muhammad s.a.w. mengikuti agama mereka.

Orang-orang Yahudi dan Nasrani tidak akan senang kepadamu hingga kamu mengikuti agama mereka. (Surat 2/alBaqarah:120).

Kemudian ayat yang menyatakan bahwa kaum Muslimin seharusnya memerangi orang-orang yang tidak beriman dan ahli kitab.

Perangilah orang-orang yang tidak beriman kepada Allah dan tidak pula kepada hari kemudian dan mereka yang tidak mengharamkan apa yang telah diharamkan oleh Allah dan RasulNya dan tidak beragama dengan agama yang benar, yaitu orang-orang yang diberi kitab, sampai mereka membayarjizyah dengan patuh sedang mereka dalam keadaan tunduk. (Surat 9/at-Taubah:29).

Ini membuat mungkin diambilnya sikap keras kepada orang-orang yang berbeda agama, di samping sikap lunak dan apresiatif kepada mereka. Alquran memang mengandung ayat-ayat yang secara sekilas memberikan pemahaman yang bertentangan dan banyak orang yang mengambil bagian-bagian yang sesuai dengan kepentingan atau cara pandang mereka saja. Ayat-ayat lain yang tidak sesuai, mereka takwilkan atau tidak mereka baca. Dalam kasus yang kita bicarakan ini, paling tidak terdapat dua kemungkinan pemahaman untuk menyelesaikan persoalan adanya dua pemahaman yang berbeda atau bahkan bertentangan ini. Pertama, memakai konsep nâsikhmansûkh. Pernyataan yang datang terakhirlah yang semestinya dipegangi, sehingga kesimpulannya adalah bahwa sikap keras kepada orang-orang beragama lainlah yang mesti dipegangi. Kedua, menggunakan konsep lain yang menyatakan bahwa pada dasarnya Alquran menghargai orang-orang yang tidak mau menerima seruannya, sepanjang mereka tidak membahayakan kehidupan umat manusia pada umumnya. Pada saat mereka membahayakan kehidupan umat manusia, sikap keraslah yang diambil. Kelihatannya jalan keluar kedua ini lebih masuk akal, namun dalam pelaksanaannya ada kemungkinan untuk terjebak dalam kesulitan penetapan sikap yang mesti diambil: kapan orang harus bersikap lunak dan apresiatif dan kapan harus bersikap keras. Manusia tidak selamanya dapat berpegang pada ajaran agama. Kepentingankepentingan, dorongan-dorongan nafsu, provokasi, perubahan keadaan jiwani dan sebagainya sering kali terlihat lebih dominan dalam menentukan apa yang dilakukan manusia. Tidak jarang pula bahwa orang lalu mencari-cari pembenaran dari teks suci atas pilihan-pilihan sekuler yang dibuatnya. Akibatnya, pada saat orang seharusnya mengambil sikap toleran, karena hal-hal 
seperti itu, orang melompat kepada sikap kedua yang keras.

\section{Persoalan Bersama}

Kalau agama menjunjung tinggi penyelamatan dan keselamatan manusia, ${ }^{9}$ maka seharusnya para pemeluk agamaagama bahu-membahu untuk menghadapi persoalan bersama ini, yakni menjaga umat manusia dan lingkungannya dari kerusakan dan pengrusakan. Ada banyak hal yang dapat diajukan sebagai contoh dalam hal ini, seperti:

1. Pertikaian antar pemeluk agama yang berbeda merupakan salah satu dari ancaman yang mesti dihadapi oleh umat beragama. Agama seharusnya membawa manusia kepada kehidupan yang lebih bermartabat, namun sering kali justru ' pemeluk-pemeluknya terdorong, tanpa sadar akan adanya kekeliruan dalam tindakan mereka, untuk melakukan tindakan-tindakan yang kurang terpuji atas nama agama. Tindakan-tindakan semacam ini banyak di antaranya yang dialamatkan kepada pemeluk agama lain.

2. Kehidupan modern yang menawarkan banyak fasilitas, terutama hiburan, sering kali dirasakan tidak membawa orang kepada kebahagiaan. Banyak nilai-nilai masyarakat yang terancam, karena, misalnya, hiburan-hiburan yang ditawarkan sering kali tidak mengalami seleksi yang cukup, padahal itu membawa serta nilai-nilai yang lain dari nilai masyarakat Indonesia.

3. Kebodohan, kemiskinan, kesempitan pandangan, klaim kebenaran, ketakberadaban dan sebagainya, sudah lama disadari adanya dan diusahakain penanggulangannya. Akan tetapi, masih saja hal-hal ini ada dan menimbulkan banyak persoalan dalam masyarakat. Umat beragama, di samping menjadi pelaku, semestinya melakukan sesuatu untuk mengurangi itu semua.

4. Ketidakadilan, kesewenang-wenangan, kemumpungan dan sebagainya, dari pihak atasan kepada pihak bawahan juga dirasakan masih saja belum dapat ditanggulangi dengan baik. Agama, terutama dengan ajaran kepatuhannya kepada Tuhan yang tak nampak, mempunyai potensi untuk mencegah berlangsungnya hal-hal seperti ini.

5. Pemanfaatan atau penyalahgunaan sentimen keagamaan oleh orang atau kelompok tertentu untuk tujuan-tujuan yang kurang sesuai dengan tujuan agama sendiri. Pelurusan hal ini menjadi tanggung jawab setiap individu pemeluk agama.

Emosi memang sering kali menguasai manusia, tidak terkecuali para pemeluk agama. Di antara ajaran spiritualitas agama, yang mungkin dapat dikatakan ada pada setiap agama, adalah penguasaan emosi. Namun anehnya, justru orang-orang beragama sering kali gampang sekali dikuasai oleh emosi ketika mereka merasa melakukan tindakan mempertahankan kesucian agama mereka. Barang kali ini berasal dari anggapan bahwa hanya agama sendiri yang benar, namun dapat juga ini berasal dari egoisme, yang dalam hal ini dimitologisasikan secara tanpa sadar menjadi tindakan keagamaan.

Dalam kehidupan modern yang antara lain dicirikan dengan kemajemukan dan keterbukaan, konsep-konsep eksklusif dari agama yang dihasilkan masa lampau tidak

${ }^{9}$ Lihat Ignas Kleden, “Kebangkitan Agama dalam Tiga Dimensi", dalam Kompas, tanggal 3 April 1995, hlm. 4 dan 5. 
dapat berjalan tanpa menimbulkan konflik yang berakibat pada kesengsaraan umat manusia. Karena itu pilihan hanya ada satu, dan ini merupakan pilihan yang sah, yakni bahwa inklusivitas mesti menjadi dasar kehidupan beragama. Bukan apa yang membedakan. aku dari kamu yang mesti disadari, melainkan banyaknya kesamaan yang menunjukkan bahwa kemanusiaan adalah satu dan karenanya pejuang kemanusiaan dengan latar belakang ajaran agama apa pun mesti menaruh perhatian kepada kemanusiaan dari orang yang berasal dari tradisi dan agama lain. Apa yang menimpa umat golongan agama yang satu mesti menjadi keprihatinan umat agama lain juga.

Masyarakat tempat kita hidup adalah masyarakat majemuk. Tidak hanya ada banyak agama, melainkan juga ada hal-hal bukan agama yang berperan seperti peran agama. Persoalan yang menim-pa sebahagian dari anggota masyarakat sering kali tidak terisolasi, melainkan mengenai yang lain-lain juga. Perșoalan-persoalan seperti yang disampaikan di atas sama sekali bukan persoalan yang terisolasi pada sekelompok masyarakat atau segolongan pemeluk agama, melainkan persoalan seluruh anggota masyarakat.

Kalau tujuan semua agama-agama pada dasarnya sama, yakni pemuliaan hidup manusia, maka tidaklah wajar kalau pemeluk satu agama menganggap bahwa jalan yang ditempuh untuk menyelesaikan persoalan itu hanya jalan yang ditawarkan oleh satu golongan. Juga sering kali terbukti, jalan-jalan dalam kesendi-riannya itu mempunyai beberapa kelemahan. Mengapa, untuk per-soalan-persoalan bersama tidak diambil jalan bersama pula?

Yang pertama kali harus dilakukan adalah pembenahan diri sendiri. Masingmasing dari kita adalah manusia yang mempunyai perasaan. Maka dari itu, kalau saya tidak mau orang lain menyinggung perasaan saya, saya pun seharusnya tidak menyinggung perasaan orang lain. Tenggang rasa seperti ini mesti diperluas sehingga mencakup keinginan, harga diri, keimanan, kesulitan, kekonyolan, kenaifan, kefanatikan, kesempitan pandangan, kebutuhan hidup, keterikatan dengan kelompok dan sebagainya.

Semestinyàlah dikembangkan kesadaran bahwa kita sama-sama manusia dengan kelebihan dan kekurangan, yang mesti hidup dalam masyarakat untuk kemuliaan bersama. Ini tidak mudah, karena kita dibesarkan dengan "ajaran" agama dan tradisi yang sering kali tercemar oleh paham yang tidak mengakui keberadaan orang lain. Rasionalitas sering kali tidak jalan menghadapi ini semua.

Manusia, baik sebagai individu maupun kelompok, tidak dapat mengisolasi diri terus menerus. Setiap orang memerlukan orang lain untuk memenuhi kebutuhan hidupnya dan karena itu ia mesti bergaul, menjalin hubungan dengan orang lain.

Kompetisi sebagai sebuah mode di zaman global semestinya dibarengi dengan kerja sama. Pilihan yang wajar ketika orang tidak dapat menang dalam berkompetisi adalah berkompromi dengan pesaing yang menang. Akan tetapi, sebenarnya semangat kerjasama mestilah dipegangi erat-erat sejak permulaan. Dasar yang paling penting adalah bahwa tidak ada orang atau kelompok yang dapat hidup dan menyelesaikan sendiri persoalan kehidupan, sementara persoalan yang dihadapi banyak dan beban yang mesti ditanggung sangat berat.

\section{Pendekatan Konflik}

Mengenai konflik, dapat dibangun teologi bahwa konflik sangat merugikan 
spiritualitas manusia, yang sangat ditekankan dalam beragama. Konflik yang dilanjutkan dengan penggunaan kekerasan akan menyuburkan dominasi nafsu amarah atas diri. Tindakan yang berlabel agama, ketika didorong oleh nafsu amarah, menjadi tidak mempunyai nilai keagamaan, karena pada hakekatnya merupakan pelampiasan nafsu amarah. Konflik juga kontra produktif bagi dakwah, ajakan ke jalan Allah. Bagaimana mungkin orang yang menjadi lawan kita dalam konflik dapat melihat kebenaran dari tindakan kita? Selain itu, konflik juga menghilangkan modal sosial yang sangat penting: kepercayaan di antara warga masyarakat. Tanpa kepercayaan di antara warga, kebaikan apa yang dapat dibangun? Enerji yang dikeluarkan dalam konflik pun jauh lebih besar daripada yang dikeluarkan dalam keadaan tiak ada ketegangan.

Islam mengajarkan kepada umatnya untuk menghindari tindakan yang merugikan diri sendiri atau orang lain, ${ }^{10}$ boros dalam membelanjakan milik"11 dan membuat kerusakan di bumi. ${ }^{12}$ Ketiga-tiganya terpenuhi dalam konflik, bahkan dengan kontraproduktifitas konflik atas dakwah, argumen penolak pemakaian konflik menjadi empat. Ini pun masih dapat ditambah lagi.

Pelaku-pelaku dalam konflik masyarakat kadang-kdang tidak jelas sosoknya. Banyak dari kerusuhan bersifat massal dan tidak dapat ditimpakan tanggung jawabnya kepada individu. Sementara itu kelompok yang kepadanya ditimpakan "dosa" berkonflik itu kemungkinannya sangat kecil dan terdiri dari orang-orang yang sepenuhnya setuju dengan konflik. Lebih sering ditemukan adanya orang-orang yang tidak setuju dengan konflik atau segera menghendaki rekonsiliasi. Kalau orang-orang seperti ini dapat tampil ke depan untuk mengambil inisiatif menghubungi orang-or- ang di pihak lain yang seide, rekonsiliasi akan segera dapat diusahakan.

Perseteruan tidak selamanya direstui oleh orang-orang yang memegang kewibawaan dan kewenangan atas kelompoknya. Tidak jarang ditemukan orang-orang yang lepas dari kontrol pemimpin walaupun hanya sesaat dan terlibat dalam tindakan yang tidak bertanggung jawab, seperti konflik. Dalam keadaan seperti ini, inisiatif rekonsiliasi akan dapat segera muncul. Akan tetapi, tidak jarang pula bahwa konflik memang berasal dari pemegang kendali kelompok, sementara orang-orang yang menginginkan rekonsiliasi berada di pinggir dan tidak mempunyai kapasitas untuk menghembuskan angin rekonsiliasi. Meskipun demikian, optimisme tidak mesti diputuskan. Yang diperlukan adalah bagaimana mendorong orang-orang seperti untuk tampil dengan sikapnya dan menjadi pembuka pintu rekonsiliasi. Pihak luar memang dapat efektif mempertemukan pihak-pihak yang berseteru, namun akanlebih baik kalau kemauan dan tindakan untuk bersatu kembali justru datang dari

10 Hadis $\mathrm{Nabi}$, tidak boleh dilakukan perbuatan yang merugikan diri sendiri dan tidak pula yang merugikan orang lain. Dapat juga dibaca, janganlah kamu sengaja mencampakkan diri kamu ke dalam kebinasaan (2/al-Baqarah: 195).

"Dan berikanlah kepada kerabatmu, dan orang miskin serta orang musafir haknya masing-masing; dan janganlah engkau membelanjakan hartamu dengan boros seboros-borosnya. Sesungguhnya orang-orang yang boros itu adalah saudara-saudara Syaitan, sedang Syaitan itu adalah makhluk yang sangat kufur kepada Tuhannya. (17/alIsrâ': 26-7).

${ }^{12}$ Dan janganlah kamu mengurangi hakhak orang ramai, dan janganlah kamu bermaharajalela melakukan kerusakan di bumi (26/al-Syu'arâ': 183). 
dalam kelompok-kelompok yang sedang berseteru.

Damai lebih murah dan menyenangkan daripada konflik. Untuk konflik, orang memerlukan energi. Bayangkan keadaan orang yang ada dalam ketegangan dengan tetangganya. Betapa ia mesti memasang wajah kelam setiap kali bertemu dengan tetangganya itu, sementara untuk berwajah kelam itu ia mesti menegangkan otot-otot di wajah dan sekitarnya. la juga mesti bersiap-siap, karena kecurigaan, atas kejutan buruk dari "lawannya" itu. Kalau perlu ia juga mesti mengambil jalan yang lebih jauh atau lebih sulit untuk menghindari pertemuan dengan orang yang tidak disukainya itu. Sudah barang tentu itu semua menghabiskan banyak enerji dan menyulitkan keadaannya sendiri.

\section{Daftar Pustaka}

Abdullah, Taufiq, 1989, "Agama Sebagai Kekuatan Sosial", Methodologi
Penelitian Agama; Sebuah Pengantar, Yogyakarta: Tiara Wacana.

Departemen Agama RI., 1990, Yayasan Penyelenggara Penterjemah AlQur'an, Jakarta: CV. Kathoda.

Kitagawa, Joseph M., 1958, The Comparative Study of Religion, New York: Colombo University Press.

Kleden, Ignas, 1995, Kebangkitan Agama dalam Tiga Demensi, Jakarta: Kompas.

Presentasi Penulis, "Faith and Identity" dalam acara "The Christian - Muslim Dialoge Consultation", Yogyakarta: Lutheran World Federation (LWF Genewa) UKDW., 4-6 April 2002.

Steen Brink, Karel. A., 1997, "Im Ages of Ișlam in Dutch Society", tt, Jakarta. 